\title{
Cross-Border Cooperation as Part of the Irish Peace Process: Opportunities, Impacts And Challenges
}

\author{
UDK: $327.36(417)$
}

Andy Pollak

Centre for Cross Border Studies, Northern Ireland

a.pollak@qub.ac.uk

\section{ABSTRACT}

Cross-border cooperation between Northern Ireland and the Republic of Ireland emerging out of the 1968-1998 conflict is an important and largely successful dimension of the peace process in Ireland, with institutional cooperation between the two governments on the island playing a key role. This article looks at the level of interaction between North and South on the island; asks what role the EU has played in this process and what are the challenges of measuring the impact of such cooperation; outlines the work of the Centre for Cross Border Studies, and looks ahead to the challenges facing cross-border cooperation in a period of severe financial and economic constraints.

Key words: Ireland, cross-border, cooperation, peacebuilding

JEL: R5, ZO

\section{Introduction}

The Irish border region is a peripheral, largely rural region composed of six counties in Northern Ireland and six counties in the Republic of Ireland', which shares most of the characteristics of such regions throughout Europe: small farms, poor soil, little industry except in a few towns, high unemployment and high outward migration. The main difference with

\footnotetext{
1 The six counties in Northern Ireland are Antrim, Armagh, Down, Londonderry, Fermanagh and Tyrone; the six counties in the Republic of Ireland are Cavan, Donegal, Leitrim, Louth, Monaghan and Sligo.

Pollak, A. (201 1). Cross-Border Cooperation as Part of the Irish Peace Process:

Opportunities, Impacts And Challenges

Uprava, IX(2), 135-144.
} 
similar European border regions is that this area suffered particularly badly during the Northern Ireland conflict which largely ended in 1998 (although small armed republican groups remain active). It experienced a brief period of prosperity during the "Celtic Tiger" period of rapid economic expansion in 1995-2007 but with the collapse of that boom, unemployment and emigration have returned with a vengeance.

It is now nearly 17 years since the first Irish Republican Army (IRA) ceasefire and over 13 since the 1998 Belfast/Good Friday Agreement, signed by the British and Irish governments and the warring parties in Northern Ireland, effectively brought to an end 30 years of conflict. It is four years since the head of the most militantly pro-British Unionist Party, Rev lan Paisley, and the former senior IRA commander, Martin Mc Guinness - after nearly 40 years of trying to bomb and shoot Northern Ireland into a united Ireland - completed the virtuous circle by sitting down in government together as First Minister and Deputy First Minister of a regional government.

An important dimension of the 1998 Agreement was the establishment of seven North/South inter-governmental bodies (under a North South Ministerial Council) to administer, on a cross-border basis, important elements of tourism, trade and business development, inland waterways, EU funding programmes, minority languages, food safety and aquaculture. These bodies provide an inter-jurisdictional architecture - the outcome of an international agreement - which is unique in Europe, and probably in the world (Coakley \& O'Dowd, 2007).

\section{Economic and Political Cooperation}

This has been a long journey and cross-border cooperation between Northern Ireland and the Republic of Ireland - both at governmental and non-governmental level - has been an integral part of its extraordinary conclusion. Some say that, along with the reform of policing, it is one of the real success stories of the Northern Irish peace process. At a high-level meeting of officials from the Department of Foreign Affairs in Dublin about North-South cooperation in Ireland three years ago, the achievements of the previous decade of cooperation between the Republic of Ireland and Northern Ireland were listed, and they made for an impressive list. In that summer of 2008, the Irish Taoiseach or Prime Minister was promising that hundreds of financial services jobs would be farmed out from Dublin to Belfast; the Irish Government was proposing to 
spend nearly 600 million Euros in roads in Northern Ireland; there was a newly-opened all-island single electricity market; North-South trade had doubled in the previous decade; Northern Irish firms were queuing up to join Irish government trade missions. That was, of course, before the cataclysm which hit the Irish banking system in 2008 and the discovery that the Republic of Ireland - its banks, its property developers, its government - had built the booming "Celtic Tiger" economy on a mountain of unsustainable debt of near-world record proportions. We are now suffering the consequences of that financial and governmental folly.

If the economic picture now looks grim, on the political front in Northern Ireland and between North and South the moves towards peace and cooperation have continued. The ancient antagonists of the Democratic Unionist Party (formerly headed by the Protestant fundamentalist clergyman Rev lan Paisley) and Sinn Fein (the party of the IRA) are still meeting regularly and cordially (along with the Irish Government) to discuss and oversee North-South cooperation in everything from transport to trade, education to health, and tourism to agriculture, while 700 officials from both jurisdictions (in the specially established North-South inter-governmental bodies) jointly implement their decisions. Much of this cooperation has been relatively superficial, and has had little impact on core services in the two jurisdictions. Nevertheless, given the bloody events of the past half-century, it is the stuff of miracles that the Democratic Unionist Party now has a say in how the Republic's canals are run, while the Irish Government has funded a new road between Belfast and the ultra-loyalist (i.e. strongly pro-British) port of Larne.

\section{European Union (EU) role}

At the same time, the European Union (EU) has pumped money into Northern Ireland and the border counties of the Republic of Ireland. For much of the past two decades the EU - mostly through the Belfast-based Special EU Programmes Body, itself one of the inter-governmental crossborder bodies set up under the 1998 Belfast/Good Friday Agreement has given out an enormous amount of money to a very wide range of projects in that small, distant, relatively under-populated part of Europe: more than 2.5 billion Euros to over 23,000 infrastructural, economic, environmental, educational, training, social, cultural and other projects. This has been mainly through two programmes: the Peace programme, a dedicated fund to assist Northern Ireland and the Irish border counties, 
and INTERREG, the wider European cross-border programme. The primary aim of a large proportion of the funded projects has been either to lower inter-communal barriers between Catholics and Protestants inside Northern Ireland, or to lower the economic and social barriers between Northern Ireland and the Republic of Ireland.

The Centre for Cross Border Studies is both a product and a beneficiary of this European largesse, and has been to the forefront of both researching and developing this cross-border cooperation. Since its foundation in 1999 the Centre has carried out more than 80 cross-border research projects ranging from teacher education to local government, health services to sustainable development, animal disease to telecom technologies, Information and Communication Technology (ICT) to services to migrant workers; organized 60 cross-border conferences and seminars; provided the secretariats for three new all-Ireland networks bringing together universities, teacher training colleges and spatial planners; trained over 140 government and local authority officials in cross-border cooperation; and created major publicly accessible databases providing cross-border information for researchers and policy-makers ${ }^{2}$ and practical information for cross-border workers and commuters $^{3}$. The Centre's latest package of research, information and training projects, funded by INTERREG and grouped under the common title Ireland/Northern Ireland Cross-border Cooperation Observatory (INICCO), covers regenerating the border region economy, cross-border spatial planning, cross-border hospital services, cross-border citizens information, and measuring the impact of cross-border cooperation. The last of these projects - undertaken in collaboration with the Euro-Institut in Kehl, Germany - has produced a pilot Impact Assessment Toolkit for cross-border cooperation in Ireland which is believed to be the first of its kind in Europe, and a number of EU agencies have expressed an interest in seeing it adapted to other border regions. (Beck, Rihm \& Taillon, 2011).

The Centre has been widely recognised for its work in building and managing cross-border and all-Ireland higher education networks. Its most successful such network is the Standing Conference on Teacher Education, North and South (SCoTENS): a network of 34 universities,

2 Cf. www.borderireland.info(2.10.2010).

3 Cf. www.borderpeople.info(2.10.2010). 
colleges and other organisations involved in the training of teachers. This was a sector which did relatively little research in either part of Ireland up to 10 years ago. During the past decade SCOTENS has encouraged cross-border research in teacher education and used small grants to support more than 70 research projects bringing together partners from Northern Ireland and Republic of Ireland (McAllister \& Pollak, 2010).This is a classic example of an innovative cross-border initiative which fills a gap which was not being filled in the two jurisdictions separately. The Centre believes that there are probably similar gaps all over Europe where an absence of provision within a national jurisdiction can be filled by an innovative, dynamic cross-border initiative. This is a good example of what Dr Joachim Beck, Director of the Euro-Institut - a leading European authority on cross-border cooperation - calls »development of common potentials through cross-border cooperation« (Beck, 2011 ).

\section{Opportunities}

So we have had a decade of great opportunities for cross-community peace-building between Protestants and Catholics in Northern Ireland and cross-border cooperation between North and South in Ireland. Have we used them well? The evidence points to greater progress on lowering barriers between Northern Ireland and the Republic of Ireland than overcoming barriers between the nationalist (and overwhelmingly Catholic) and unionist (and overwhelmingly Protestant) communities within Northern Ireland.

The Northern Ireland First Minister Peter Robinson - for 35 years lan Paisley's first lieutenant - has said on numerous occasions that relationships with the Republic of Ireland have never been better. Until the beginning of the economic recession in 2008, cross-border business and trade had never been higher. The security threat from the remaining IRA dissidents - small but still significant - is held in check by excellent cooperation between the two police forces. The intergovernmental crossborder bodies outlined above have sometimes had to cope with squabbles among the coalition of ancient enemies that forms the regional government of Northern Ireland - but their officials continue to work quietly and in the main effectively across the border. Fuelled by the generous EU funding outlined earlier, community and voluntary groups have been particularly active in making connections across that border, although the volume of this work is less now that the funding is running 
out. Conor Brady, a former editor of the country's main newspaper, the Irish Times, summed it up well in 2005, when he wrote (Brady, 2005):

"The cold denying silence that fell upon the island in the 1920s has all but ended. Right across public life - in public services, in business, in Non Governmental Organizations (NGO), in voluntary organizations - the deadly, deafening silences and the stopped-up channels of communication have been replaced by dialogue, cooperation and a realization that everyone gains, and nobody loses, when people and organizations work together. Of course it does not all flow from the Good Friday Agreement. There have been decades of on-the-ground work put in by clubs, volunteers, schools, organizations, churches and so on. But what the Agreement has done is to make it possible, acceptable and necessary for official Ireland, North and South, to get on with the everyday business of life - together."

\section{Measuring the impact}

Despite these complimentary words from a leading journalist, it is not easy to measure the impact of all this cross-border activity on the postconflict landscape. In fact, it is notoriously difficult to quantify the impact of such post-conflict peace and reconciliation initiatives, since they are inevitably long-drawn-out processes based on slowly improving relationships and patiently increasing understanding. Many of the interim evaluations have been positive. For example, an authoritative 2005 study of the Irish border region found that the Peace programme had sdone much to underpin the peace process by providing close cooperation between civil society organizations and political leaders at local level. The programme validated work between ex-combatants and promoted their social and political reintegration. Cross-border work won increasing acceptance, was seen to be a norm and became less threatening to the loyalist (i.e. Protestant and Unionist) community« (Harvey et al., 2006).

Similarly, the conclusions of a research study by a team of political scientists and psychologists from University College Dublin and Queen's University Belfast among 130 families and over 1000 young people in the Irish border region in 2004-2006, exploring changing intergenerational attitudes towards identity and nationality in that region, were very positive. The researchers concluded that present British and Irish government and EU policy sto encourage cross-community and cross-border contact is 
on exactly the right lines, and should be extended. This is the way in which lasting change can be provoked in enough individuals to percolate through entire communities". They warned, however, that this would be a long-drawn-out process and sit would be counter-productive to demand immediate and measurable results from cross-community and crossborder initiatives" (Todd et al., 2006). Unhappily, far from being extended, financial constraints at both EU and national government levels - with the Irish government being forced by the present recession into probably the most drastic spending cuts of any EU government outside Greece - have led in the past three years to such programmes being cut back.

Certainly, the number of people involved in these EU funded projects is impressive. The head of the EU Special Programmes Body in Belfast, Pat Colgan, said at a conference organized by the Centre for Cross Border Studies in 2008 that 450,000 people had benefitted from EU funded projects over the period from 1995 to 2008 (that includes both crosscommunity projects inside Northern Ireland and cross-border projects with the Republic of Ireland), of whom 130,000 had participated in crossborder activities. This is in a region of around 2.5 million people.

The EU's role has been vital in underpinning this great volume of cross-border work between Northern Ireland and the Republic. In the words of Queen's University Belfast sociologists Cathal McCall and Liam O'Dowd, the distinctiveness of the EU's contribution to this work lies »in the extent to which is seeks to de-territorialise the [Northern Ireland] conflict, i.e. to build cross-border networks of cooperation around issues of common interest. In this sense, it seeks to move beyond bounded territory to the creation of a cooperative transnational space» (McCall \& O'Dowd, 2004).

As has already been said, measuring the impact of this progress in any exact way will always be challenging. The Centre for Cross Border Studies hopes that its new Pilot Impact Assessment Toolkit for cross border cooperation in Ireland will provide the first such mechanism.

\section{Challenges}

However the challenges to peace-building in Ireland through crossborder cooperation remain great. This kind of work is slow, painstaking and expensive, and its impact must be evaluated across decades rather 
than the two or three year time-spans of many EU funded projects. Irish politicians, with their focus on the short-term electoral cycle, find it difficult to understand the importance of sustaining peace-building and crossborder cooperation over the vital longer term. Political leaders in France and Germany after the Second World War were more far-sighted, initiating and continuing to support an ambitious programme of FrancoGerman youth exchanges (starting in the 1950s) with the long-term aim of effecting a fundamental change in the way the future citizens of those two formerly warring nations would view each other. Evaluations have shown that this programme made a substantial contribution towards promoting good relations between the two countries, but this was only discernible after a generation of young people had been given the experience of participating (Trant et al., 2002). The lesson for Ireland is clear: if crossborder programmes, particularly in education and youth and community development, are to make a serious contribution to reconciliation on the island of Ireland, they must prepare for the long haul.

So far cross-border cooperation as a successful contributor to the Northern Irish peace process has been widely recognized. But the past decade and a half have been in many ways the "golden age" of such cooperation, with huge interest and support at home and abroad for the mould-breaking 1998 Good Friday Agreement and its implementation; extremely generous EU funding; and a formerly cash-rich Irish government that was able to devote significant resources to North-South cooperation. We are now entering a period when these factors will lose much of their import: both international and Irish interest in the Northern Ireland political situation and North-South cooperation on the island are now at a low point, with most people believing the continuing deep problems of political instability and communal division in Northern Ireland have been solved; the EU's Peace programme will probably run out in 2013-2014 (although there is a current rumour that it may continue for one more funding period in a reduced form), and its INTERREG programme will be turning its attention to other European borderlands further east; and the Irish Government, stricken by the worst fiscal and banking crisis in the history of the state, is facing up to extremely difficult problems closer to home. Within Northern Ireland too, the political atmosphere is not conducive to maintaining a high level of such cooperation, let alone increasing it, with the largest Unionist Party in government anxious to minimize its extent at every opportunity. 
This is the main challenge for cross-border cooperation on the island of Ireland over the next five-ten years: how to sustain the very significant work of the past decade in a harsher political and economic climate, and, if more favourable circumstances emerge, to expand it into new areas which have already been "scoped" such as the all-island and border region economy and cross-border health, higher education and spatial planning (e.g. InterTradelreland, 2006; Bradley \& Best, 2011; Butler \& Jamison, 2007; McCloughan, 2009; and Driscoll et al., 2007). For in these areas research, including research by the Centre for Cross Border Studies, has shown that such cooperation can bring significant practical benefits to the people of both Irish jurisdictions.

The Centre for Cross Border Studies and other practical peacebuilding and cross-border cooperation bodies will continue their longterm work in Ireland, a task that may take 30 or 50 or 100 years to reach fruition. There have been huge advances over the past decade and a half, to the extent that the Northern Ireland "peace process" is now seen as something of a model for overcoming age-old conflicts based on religion and nationality. An election was held in the region in May 2011 which was notable for its lack of controversy and preoccupation with "bread and butter" issues. One must remain optimistic that the island of Ireland is moving slowly towards mutual understanding and reconciliation although probably not political unity - between the people of its two jurisdictions within their common European home.

Andy Pollak is the founding Director of the Centre for Cross Border Studies (with offices in Armagh, Northern Ireland and Dublin, Ireland). He is also Secretary of the all-island higher education network Universities Ireland and the all-island teacher education network, the Standing Conference on Teacher Education North and South (SCOTENS). Before he left to start the Centre, he was successively Belfast reporter, assistant news editor, religious affairs correspondent and education correspondent with "The Irish Times", the island's principal newspaper, from 1981 to 1999. He was co-author of "Paisley" (1986) and editor of "A Citizens Inquiry: The Opsahl Report on Northern Ireland" (1993). His father's book, "Strange Land Behind Me" by Stephen Pollak, was translated into Slovene in the 1970 s. 


\section{References}

- Beck, J., Rimh, S. \& Taillon, R. (2011). Pilot Impact Assessment Toolkit for Cross Border Cooperation. Armagh: Centre for Cross Border Studies.

- Beck, J. (201 1). Patterns of Cross-Border Cooperation in Europe. Paper presented at conference on Cross-Border Cooperation in the Alps-Adriatic Region: Status, Potential and Perspectives - Learning from European Experiences, Villach, Austria.

- Bradley, J. \& Best, M. (2011). Bypassed Places? The Post-Belfast Agreement Border Region Economy. Journal of Cross Border Studies in Ireland. Armagh: Centre for Cross Border Studies.

- Brady, C. (2005). North-South cooperation: back to the future? Centre for Cross Border Studies Journal. Armagh: Centre for Cross Border Studies.

- Butler, M. \& Jamison, J. (2007). Removing the Barriers: An Initial Report on the Potential for Cross-Border Hospital Services. Armagh: Centre for Cross Border Studies

- Coakley, J. \& O'Dowd, L. (2007). Crossing the Border: New Relationships between Northern Ireland and the Republic of Ireland. Dublin: Irish Academic Press.

- Driscoll et al. (2007). Spatial Strategies on the Island of Ireland: development of a framework for collaborative action. Armagh: International Centre for Local and Regional Development.

- Harvey, B., Kelly, A., McGearty, S. \& Murray, S. (2006). The Emerald Curtain: the social impact of the Irish border. Carrickmacross: Triskele.

- InterTradelreland (2006). Comprehensive Study on the All-Island Economy. Newry: InterTradelreland.

- McAllister, P. \& Pollak, A. (Eds.) (2010). Reflective Practice: Challenges for Teacher Education. Armagh: Standing Conference on Teacher Education North and South.

- McCall, C. \& O'Dowd, L. (2004). The significance of cross-border cooperation for promoting peace and reconciliation. Paper presented at conference on Cross-border cooperation and its application in different political models, San Sebastian.

- McCloughan, P. et al. (2009). North-West Gateway Higher Education Strategic Alliance Scoping Study. Indecon Economic Consultants for Letterkenny Institute of Technology and University of Ulster. Dublin: Indecon.

- Todd, J. et al. (2006). Intergenerational Transmission and Ethno-National Identity in the Border Area. University College Dublin and Queen's University Belfast.

- Trant, A., Trant, S., Fitzpatrick, D., \& Medlycott, J. (2002). Promoting peace in Ireland through vocational training and work experience. International Journal of Vocational Training and Education 11 (1).

144 Uprava, letnik IX, 2/2011 